\title{
Cultural Roots of Values, Morals, and Religious Orientations in Adolescent Development
}

Gisela Trommsdorff

\begin{abstract}
Values, morals, and religious beliefs are organizing factors in the development of self- and worldviews. These factors are assumed to be a driving force in adolescents' agentic regulation of development, which is embedded in the cultural context and influenced by universal and culturally specific processes. Adolescents regulate their individual development by integrating values, morals, and religious purpose in line with their self- and worldviews to achieve an optimal cultural fit. First, the relations among culture, self-views, and worldviews in adolescent development are discussed. Second, selected culture-informed studies on values, morals, and religious purpose as part of self- and worldviews are presented. Third, the focus is on the developmental conditions relating these aspects. In the conclusion, a model bridging the lens of culture and the lens of adolescent development is suggested, specifying some psychologically relevant factors in this process.
\end{abstract}

Key Words: culture, values, moral, religion, adolescent development, self-view, worldview, autonomy, relatedness

But the stranger that dwelleth with you shall be unto you as one born among you, and thou shall love him as thyself, for you were strangers in the land of Egypt.

-(Leviticus 19:32)

In our studies of Japanese and German adolescents' experiencing parental influence attempts (e.g., giving orders or instructions, objecting or disapproving of an activity), Mary and John felt rather rejected or at least not supported by their parents (like most German respondents). By contrast, Yukiko and Akira (like most Japanese respondents) felt supported in cases of parental influence attempts. Different from their German peers, they felt rejected or deprived of parental support in cases of no apparent parental influence (control or monitoring). German and Japanese adolescents obviously experience and evaluate seemingly similar parenting differently (Trommsdorff \& Iwawaki,
1989). The question is whether and how the respective subjective experiences are associated with the prevailing cultural values of autonomy and relatedness or with independence and interdependence. Is parental control experienced as threatening adolescents' autonomy in a context where independence is preferred? And is it experienced as fostering interdependence in a context where independence is less valued?

In another study, we were interested in adolescents' emotional and behavioral reactions when experiencing a frustrating or disappointing situation (e.g., vignettes describing a peer who openly criticizes the student for a bad performance or making the student stumble and nearly fall down). In this situation, Lisa (like most German adolescents) reacted with anger and frustration, explaining the peer's behavior as motivated by aggressive intentions; also, she was ready to retaliate. In contrast, Japanese or Balinese adolescents, like Keiko or Sri, 
usually reacted by explaining (excusing) the peer's behavior; they did not attribute negative intentions to the peer, but instead they referred to their own possibly unruly behavior that may have caused the peer's misbehavior. As a result, their behavioral intention was not to retaliate but to restore a harmonious relationship (by ignoring the peer's behavior or mentioning "so sorry"; Kornadt, 2012; Trommsdorff \& Ibaraki, 1989, unpublished data).

These observations indicate that harmful behavior can be interpreted by the victim in very different ways - as aggression or as a mishap - and thus shape either the hostile or harmonious quality of further interactions. Here, the question can be raised whether the interpretation of the other person's behavior and the subsequent interaction sequence is based on generalized views about the self, the world, and their interrelation; that is, the belief that the world (other person) should be changed according to one's own wishes (primary control) or that the self should accommodate to the world (other person; secondary control), or a balancẻ between both.

In this chapter, I discuss whether such differences in interpretations and behavioral reactions result from adolescents' socialization of different self- and worldviews that include individual values, morals, and beliefs in line with the prevailing cultural model of independence and interdependence that are assumed to shape the meaning of autonomy and relatedness.

Culture-informed studies on adolescent development are rare. Most research on adolescent development has been carried out with European-American samples, limiting generalizations of empirical results. Textbooks on adolescence tend to refer to culture in terms of adolescents' subcultures or acculturation. Even less is known about cultural aspects of values, morals, religious purpose, and their interrelations as part of adolescents' self- and worldviews. Recently, worldwide globalization-including cultural, economic, and demographic change-has widened the perspective of developmental psychologists, as evidenced by culture-informed publications on adolescence (e.g., Arnett, 2006, 2012; Arnett \& Eisenberg, 2007; Brown, Larson, \& Saraswathi, 2002; Trommsdorff \& Chen, 2012).

Adolescence is characterized by significant biological, psychological, and social changes, with nature and nurture interacting in these dynamics. Normative and history-graded factors structure person-context relations ("goodness-of-fit") modified by adolescents' socialization in multiple sociocultural settings. Processes of adolescents' development are conceived of here in line with the ecological model of development (Bronfenbrenner 1979), the concept of developmental niche (Super \& Harkness, 1986), and the cultural model of independence and interdependence (Markus \& Kitayama, 1991). Accordingly, adolescents' development is embedded in the family, peer groups, school, work place, media, institutions, and formal or informal relationships, with cultural and biological factors shaping the respective socialization processes.

Furthermore, I view developmental processes as motivated by agency-regulating needs of autonomy, competence, and relatedness (Ryan \& Deci, 2000). Different from Bontempo, Lobel, and Triandis (1990), I do not assume collectivistic cultural populations to be less agentic than individualistic cultural populations (see Miller, Goyal, \& Wice, this volume; Trommsdorff, 2012a; 2012b).

The cultural context, as well as biological and psychological factors related to the specific developmental age, are assumed to structure the relative valence and contents of these basic needs and their impact on adolescents' self- and worldviews. Accordingly, inter- and intracultural differences in adolescents' self- and worldviews are assumed. These self- and worldviews are basic orientations that fit to the culturally preferred models and value orientations (Trommsdorff, 2012a; 2012b). In this chapter, I discuss how adolescents' self- and worldviews are integrated in and resulting from adolescents' development of values, morals, and religious purpose in their respective cultural contexts.

From a culture-informed perspective, questions arise as to which developmental processes are universal and which are culture-specific. On the one hand, adolescents universally are agents of their development, actively construing and regulating their development and dealing with various cultural tasks, challenges, and boundaries. On the other hand, adolescents' developmental conditions, tasks, outcomes, and trajectories differ across cultures, while cultural factors and individual agency interact in the process of development. Although adolescents regulate their motivational, cognitive, emotional, and social development, the ecological context and cultural models shape adolescents' selfand worldviews, including their values, morals, and religious purpose.

To summarize, the main question of this chapter is how adolescents from diverse cultural contexts construe and regulate their development by dealing with questions regarding the self, the 
world, and their interrelations. Although cultural models are assumed to provide developmental tasks and answers to these questions, adolescents have to interpret and choose from these various tasks and answers. Therefore, adolescents attempt to develop reliable and valid orientations for guiding their goals, choices, and behavior as part of their identity development. Values, morals, and religious beliefs are organizing factors in this process underlying the development of self- and worldviews - a process assumed to be a driving force in adolescents agentic regulation of development (Trommsdorff, 2012a; 2012b).

This chapter is organized into three parts: First, the relations among culture, self-views, and worldviews in adolescent development are discussed. Second, I discuss selected culture-informed studies on values, morals, and religious purpose as part of self- and worldviews. Third, I focus on developmental conditions relating these aspects. In the conclusion, I suggest a model that bridges the lens of culture and the lens of adolescent development, specifying some psychologically relevant factors in this process.

\section{Culture, Self-Views, and Worldviews Culture}

Definitions of culture abound, referring to rituals, myths, symbols, or cultural practices (Cole \& Packer, 2011). Cultures are not seen as homogenous entities but rather as processes in interaction with individual development. In their often-cited comprehensive meta-analyses, Oyserman, Coon, and Kemmelmeier (2002) have pointed out variations of psychological phenomena among and within cultures in contrast to typological approaches assuming homogeneity of cultures. While refraining from a typology of cultures, the notion of independence/interdependence has been fruitful for generalizing typical differences in the cognition, emotion, behavior, and self-construal of individuals from different cultural contexts (Markus \& Kitayama, 1991). Such differences have been seen as resulting from cultural tasks (Kitayama \& Imada, 2010) or from cultural models of agency (Markus \& Kitayama, 2004).

To capture more subtle differences in cultural contexts and related self- and worldviews of individuals, here I conceptualize culture in line with Bruner (1990) as a historically grown, shared meaning system transmitted across generations. The cultural context and related frames of meaning may change during adolescent development.
Sociocultural changes imply heterogeneity, diversity, and intracultural differences, all warning against the fallacies of a simple typological approach. Accordingly, simple dichotomies of cultural differences do not necessarily allow for the specific cultural meaning of individual values, morals, and religious behavior in the respective context. When referring to a specific society, heterogeneity should be assumed. Terms like "Eastern" and "Western" culture are therefore used here as hypothetical constructs. Concepts like independence and interdependence imply a relative priority of either value depending on the respective cultural context, situation, and developmental resources.

Cultural contexts constitute major challenges, opportunities, and limitations for adolescent development. The cultural contexts are often interrelated and based on different cultural models of agency (Trommsdorff, 2012a), shaping socialization processes and influencing adolescents' development of values, morals, and religious beliefs as part of their self- and worldviews.

\section{Self-Views}

Self-views focus on the past self, the present self, and/or the future (possible) self of the individual person in relation to his or her environment. Self-views have been conceptualized as self-construals, giving higher priority to the individual self (independence) or to the sociocultural related self (interdependence). In their theoretical approach to culture and self, Markus and Kitayama $(1991,2004)$ assume that the cultural model of independence or interdependence shapes an individual's self-construals, which mediate the influence of culture on behavior. In individualistic cultures, people are assumed to view themselves as relatively independent from others; in collectivistic cultures, people are assumed to develop an interdependent self, viewing themselves in close relation to others. For example, whereas people in European-American contexts describe themselves in terms of their abilities, traits, and unique qualities, people in East-Asian contexts describe themselves in terms of their social roles and obligations in their various relationships with others (Markus \& Kitayama, 1991). The independent/interdependent self-construal has been linked to a wide range of psychological and behavioral outcomes explaining cultural variations (e.g., with respect to cooperation, modesty, self-esteem; Oyserman et al., 2002).

Distinguishing between individual-oriented and social-oriented self-views should provide a theoretical culture-informed approach for studying 
adolescents' values, morals, and religious purpose. However, a simple dichotomy cannot fully account for the interacting and rebounding factors in the dynamics of culture and development. The Hindu conceptualization of the self differentiating between the present and the transcendental self (Mishra, 2013; Saraswathi, Mistry, \& Dutta, 2011) is an example for the close relations among self-construal and cultural values, morals, and religious beliefs.

Across cultures, various other aspects of self-views and manifestations of the need for positive self-evaluation have been shown. Self-views related to a promotion- or prevention-focused motivation serve to enhance and protect one's self-worth (and self-efficacy) in line with the cultural model of self (e.g., Hepper, Sedikides, \& Cai, 2013). Individuals who prefer interdependent values orient their self-system in a way to protect and enhance social harmony - a moral obligation' in East Asian cultures. Relationship harmony allows for experiencing a positive self-concept and related well-being for Asian people (Kim \& Tov, 2011). East Asians have been observed to be more likely than European Americans to take into consideration the perspective of other persons in their self-view (Cohen \& Gunz, 2002). This tendency may affect the development of values and morality such that rule-oriented behavior is more readily activated (cf. Gelfand et al., 2011).

Another aspect of cultural differences in self-views is related to implicit theories of personality, more specifically, the preference of a fixed (entity) or a malleable view of the self influencing the person's motivation and goal setting (e.g., regarding achievement, aggression, or self-regulation; Dweck, 1999; Rothbaum \& Wang, 2010). A malleable or incremental view of the self motivates the person to engage in further efforts in case of failure in an achievement situation. Accordingly, effort is highly valued in Asian cultures.

Adolescents' development of self-views includes the selection of possible selves (Markus \& Nurius, 1986) as aspects of future orientation (Seginer, 2009; Trommsdorff, 1983). Narratives from Muslim girls how that collectivistic and individualistic themes are combined, and collectivistic themes were much more pronounced 10 years ago (Seginer, personal communication, September 21, 2013). An ultra-orthodox Jewish girl says: "I want to study nursing because I want to help people and give them all the human kindness in me." A Muslim girl says: "I want to serve my people and in addition to getting higher education also study religious studies so that I can teach everyone to be close to religion and our nation." These examples may illustrate that the development of self-views is shaped by the cultural model of self, including cognitive and motivational aspects of self-other relations (e.g., autonomy, competence, relatedness) relevant for adolescents' development of values, morals, and religious purpose.

\section{Worldviews}

Self- and worldviews are influenced by the cultural models for agency and include beliefs about the fixed or malleable quality of the self and the world and related control beliefs (e.g., primary and secondary control; harmony control; Morling \& Evered, 2006; Rothbaum \& Wang, 2010, 2011; Trommsdorff, 2012a). Worldviews are generalized beliefs about free choice (individualistic value) and acceptance of fate and circumstances (collectivistic value). Referring to the earlier narrative, German adolescents' beliefs about free choice activates their resistance to parental control; in contrast, the Japanese adolescents' belief in acceptance of circumstances allows for acceptance of parental control.

Self-views and worldviews are interconnected (Rothbaum, Wang, \& Cohen, 2012). In the search for orientation and identity, adolescents strive to find answers to questions about how the self and the world are related. In some cultures, socialization fosters the child's view of the world as fixed and as exerting causal agency while also fostering a view of the self as malleable and accommodating to the world. This self- and worldview is the basis for secondary control, a behavior motivated to change the self to fit the world. By contrast, socialization experiences fostering the child's autonomy instead tend to foster the child's view of the world as malleable and as accommodating to the child's needs. This view of the self and the world underlies primary control, a behavior motivated to change the world to fit the self (Rothbaum \& Wang, 2010; 2011). In the introductory example, Keiko and Sri act according to a self- and worldview of secondary control, refraining from retaliation and instead searching for their own mistakes, whereas Lisa intends to retaliate, acting in line with a self- and worldview of primary control. However, it would be wrong to conceptualize primary and secondary control as mutually exclusive because both usually are more or less available to the individual person, in balance, or one can have priority, depending on 
developmental age and the cultural and situational context. Worldviews can focus on the material and/ or the nonmaterial, supernatural world. The material world is structured according to one's experiences with other persons (parents, peers), social groups, social institutions, and the physical and natural environment. The supernatural "other" world is structured according to cultural values and intuitive theories about the nonmaterial world related to religious beliefs and spirituality.

When adolescents experience minor and major threats to their self- and worldviews, they react depending on combinations of risk and resilience, contextual, and personality factors (Eisenberg \& Silver, 2011). Different kinds of self-regulationprimary control (changing the situation) and/or secondary control (changing the self by acceptance of the circumstances, restructuring one's goals) allow for successful coping. An example for primary control in the case of experiencing major threats to their self- and worldviews is when adolescents engage in disobedience or aggressive behavior in order to protect their values and moral intuitions.

In our introductory narrative example, the Japanese (or Balinese) youths' focus on limited trust in their own efficacy (or on their own wrongdoing) results in secondary control-accommodating to the other person (controlling parent; disruptive peer) and attempting to foster a harmonious relationship. In contrast, the German youth experiences a threat to the value of autonomy and independence and reacts with primary control (and feels morally justified to react against parents or retaliate against peers).

Self- and worldviews develop in the cultural context and serve as foundation for agency, fueling individual values, morals, and religious beliefs. Self- and worldviews provide meaning and guide adolescents' agentic development. A Muslim girl from Seginer's study says: “The things I would like to happen to me is be a high achieving student and peace between the Arab nations and especially the Palestinians and Israel" (personal communication, September 21, 2013). This narrative may illustrate the theoretical frame of this chapter: values of autonomy and relatedness and moral and religious purpose are part of self- and worldviews in adolescent development.

\section{Values, Moral, and Religious Orientations as Part of Self- and Worldviews}

According to Brewer and Chen (2007), culture provides answers to basic questions about the self, the world, and the goals to which one should aspire through socialization and interaction processes. Values, morals, and religious purpose in part serve to answer these basic questions, which are of special importance in adolescence.

\section{Values}

Individual values are part of self- and worldviews and function as a motivational force and as desirable goals. Schwartz defines individual values as "trans-situational goals, varying in importance that serve as guiding principles in the life of a person" (Schwartz, 2011, p. 464). Schwartz applies two theories of value-related constructs: a cultural level theory and an individual level theory. Cultural value orientations function to regulate and organize societies; they reflect historical, sociostructural, economic, and ecological factors of societies. Individual values are related to individual needs.

The psychological function of individual values may vary according to the prevailing cultural model. For example, Rothbaum, Pott, Azuma, Miyake, and Weisz (2000) have pointed out that the different developmental trajectories of US and Japanese adolescents are based on different values of autonomy and relatedness. The authors characterize adolescents' developmental path in the United States according to the values of independence and self-direction and in Japan by the values of interdependence and relatedness. Other studies suggest a cultural family model. Kagitcibasi's $(2007,2012)$ family change theory distinguishes "independence" (prevailing in the urban Western middle-class family), "total interdependence" (associated with obedience and prevailing in the traditional rural family), and "psychological interdependence" (with focus on the autonomous-related self, involving both autonomy and connectedness in modernizing societies). Based on cross-cultural studies of adolescents' family values (as part of the Value of Children [VOC] Study), Mayer (2013) has recently challenged this family change theory by reformulating the family model of emotional (psychological) interdependence, taking into account the weakening of emotional interdependence in family relationships during modernization (see also Trommsdorff \& Mayer, 2012). In their cultural view on socialization, referring to the cultural model of agency, Rothbaum and Trommsdorff (2007) argue that autonomy and relatedness coexist in Western societies, whereas, in many East Asian societies, autonomy 
is perceived as threatening relatedness and the need to belong. Here, emotional interdependence is seen as most relevant and as providing the basis for assurance, in contrast to trust, which has to be negotiated between separate parties (Trommsdorff \& Rothbaum, 2008). However, empirical studies are needed to specify the degree of emotional interdependence characterizing the culture-specific meaning of autonomy and relatedness (and its mutual relationship) in different cultural and situational contexts and its function for adolescent development.

Individual values represent priorities in life and have a motivational function. Therefore, individual values guide adolescents' identity development and goal setting (e.g., Saroglou \& Hanique, 2006). Although individuation and an increased preference for autonomous behavior have been reported for Western adolescents (Collins \& Steinberg, 2006), inconsistent results have been reported for hon-Western adolescents (Fuligni, 1998). With regard to family-related values, multilevel cross-cultural studies based on data from the VOC study (Trommsdorff \& Nauck, 2005) show associations among adolescents' values and family-oriented future orientation (Mayer \& Trommsdorff, 2010; 2012). For ultra-orthodox Jewish girls, keeping a Jewish home, having a big family, and bringing up children in the best of Jewish religious values is seen as women's most important destiny. Family values (obligation, deference) are so obvious and self-evident that they are not even mentioned in narratives about the future by adolescent girls. Adolescents from cultural contexts promoting individualistic as compared to interdependent self- and worldviews prefer less close family relationships. This may affect their willingness to support aging parents or which kind of support (financial, instrumental, or emotional support) they would provide (Schwarz \& Trommsdorff, 2005). Further, parentadolescent relationships in wealthy modern societies (with higher Human Development Index scores) are more characterized by conflict (Trommsdorff $\&$ Mayer, 2012). Data from the VOC Study on cultural differences in the importance of traditional family values of interdependence at a cultural level were associated with higher subjective well-being of younger adolescents (Schwarz et al., 2012).

It can be assumed that a cultural model of interdependence fosters the importance that adolescents' give to family values. However, in line with the approach by Rothbaum and Trommsdorff (2007), more specific definitions of this cultural model are necessary to allow for better understanding of the relative meaning of the respective family values. For example, the narrative earlier related shows that when the value of close emotional interdependence is not compatible with autonomy, the Japanese or Balinese adolescent instead feels supported by controlling parents. This is different from German adolescents, for whom autonomy and relatedness are associated based on less close emotional interdependence. Emotional interdependence may be fueled by shared cultural traditions. For example, in Japan, amae (see Doi, 1973), a specific kind of (mutual) dependency between mother and child, is the basis for close emotional relatedness.

In Chinese (and other Asian) cultures, the value of filial piety is an important part of the Confucian value system; it involves obedience to parents and attendance to parents' needs. Filial piety is based on family values that refer to reciprocal relations between adolescents and their parents and to emotional and material responsibilities and obligations across the life span (Chao \& Tseng, 2002). According to Confucian ethics, filial piety is rooted in filial emotions of gratitude toward parents and filial values (Cheah, Bayram Özdemir, \& Leung, 2012). Accordingly, filial piety can be an indicator for family values of strong emotional interdependence.

Rural and urban Chinese adolescents differ in their attitudes toward family obligations and the value of filial piety (Fuligni \& Zhang, 2004), indicating heterogeneity of culture. Furthermore, sociocultural changes may affect value changes. Cheah et al. (2012) discuss whether a decrease in reported filial behavior of Chinese-Malaysian adolescents indicates a process of individuation similar to that of Western adolescents. In their indigenous, child-centered approach on filial beliefs and values, Yeh and Bedford (2004) point out intracultural variance by further differentiating aspects of filial values. They demonstrate that reciprocal filial beliefs based on close, affectionate parent-child relationships decrease parent-child conflicts more than do authoritarian filial beliefs focusing on obedience and indebtedness to parents.

Chinese adolescents' focus on duties and family cohesion (Cheung, Lee, \& Chan, 1994) is in contrast to the Western belief in children's rights and independence (Kuczinsky, 2002). Research on filial beliefs and values (e.g., Yeh \& Bedford, 2004) provides specific cultural explanations for the importance of family relations, indicating communal values that impact the development of value-based 
moral beliefs. Accordingly, filial piety characterizes the values and moral purpose of adolescents in most Southeast Asian and East Asian countries, indicating psychological conditions beyond the cultural model of interdependence (e.g., the motivating dynamics of adherence to moral purpose). Filial piety is part of a culture-specific self- and worldview to which these adolescents are socialized.

As our studies on the value of children in different cultural contexts have shown, in most countries, adolescents prefer to have children for fulfilling their need for emotional bonds. The emotional value of children has increased while the material (economic and social) value of children has decreased globally during modernization, remaining only important in traditional, less affluent societies with higher values of interdependence (Mayer \& Trommsdorff, 2010; Mayer, Trommsdorff, Kagitcibasi, \& Mishra, 2012; Trommsdorff \& Mayer, 2012). However, the emotional value of children, which is rather high in traditional and modern societies, may have a different meaning depending on cultural values, as Mayer (2013) has pointed out.

Another value related to the cultural model of interdependence is the importance of self-regulation in the service of the group; for example, by saving face and behaving in ways that will not cause others (especially one's family) to lose face or by promoting group harmony. Self-regulation according to this value implies qualified knowledge of social (e.g., parental) expectations, as well as the ability and motivation to self-regulate in the service of relatedness (e.g., following social rules, obeying parents' orders, succeeding in school). Controlling one's own impulses is an important value in most cultures and can be seen as an indicator of secondary control; however, it can serve different goals (Trommsdorff, 2012a).

Related to the value of saving face is the value of focusing on others in contrast to focusing on the individual self (Cohen \& Gunz, 2002; Rothbaum et al., 2012). Focusing on others serves the value of relatedness and strengthens empathy and perspective taking by striving for social harmony. Here, the worldview of secondary control (changing the self) has priority. In contrast, focusing on the self promotes the values of independence and autonomy while accepting social conflict. Here, the worldview of primary control (changing the world) has priority. Accordingly, different from Western control theories (Heckhausen, 2002), a cultural approach to control beliefs attributes primacy not necessarily to primary control but, in the case of a cultural model of relatedness, primacy is instead related to secondary control. Self-regulation aiming to serve goals of the social group contrasts to self-regulation aiming to promote one's individual goals of independence, separateness, uniqueness.

Although this contrast is an oversimplification that disregards intracultural variance and changes in priority during adolescent development, research on the function of cultural values has shown considerable differences between Western and Eastern cultural contexts such as focusing on the individual self versus focusing on others (on social rules, on the environment, or on situational settings). However, individual values and related behavior can change when affected by sociocultural changes, the developmental age of the adolescents, and situational demands, as Chen, Wang, and Liu (2012) have shown for Chinese adolescents in their longitudinal study.

So far, values have been discussed as underlying and fueling self- and worldviews. Values are aspects of cultural contexts and motivating factors for adolescent behavior in various domains of life. Adolescent values are affected by sociocultural and economic changes (e.g., modernization, rising affluence); however, at the same time, they can affect sociocultural processes through group and individual behavior in various social contexts. A selfand worldview focusing on independence and individual rights is related to emotions, cognitions, and behavioral reactions that are different from a self- and worldview focusing on interdependence and relatedness. This can be seen in our example of German and Japanese adolescents' reactions to parental control or to a peer's wrongdoing. In the next section, I discuss in how far moral emotions are associated to the adolescents' preference for values related to independence or interdependence.

\section{Moral Purpose}

Moral development in adolescence has been viewed as the period during which the moral identity is established (Blasi, 1993). Morality develops in the cultural context, guided by cultural values. For example, dimensions of cultural values (measured at the cultural level) are related to adolescents' development of self, morals, and religious orientations (Bond, Lun, \& Li, 2012; Kasser, 2011; Schwartz, 2012). However, due to its universalistic stage-based cognitive approach to moral reasoning (Kohlberg, 1984), the majority of research on moral development has, until recently, ignored the 
role of culture. Other shortcomings of traditional research on moral development are neglecting the roles of emotions and of situational and intervening variables influencing moral judgment and social behavior (e.g., Gibbs, Basinger, Grime, \& Snarey, 2007; Turiel, 1983).

Research on moral emotions has been growing recently, due in part to evolutionary psychological approaches and their possible biological basis ("innate" morality). Topics of interest include the roles of altruism and empathy in prosocial behavior (Eisenberg, Morris, McDaniel, \& Spinrad, 2009; Rothbart, 2011) and the role of moral emotions attributions for adolescents' pro- and antisocial behavior (see meta-analysis by Malti \& Krettenauer, 2013). Haidt (2007) contrasts moral reasoning and moral intuition, suggesting a Social Intuitionist Model that assumes automatic, affect-laden processes resulting in positive and negative emotions.

Anthropological and cross-cultural studies have demonstrated the limits of the traditional universal cognitive theory of moral development (e.g., Miller 1997, 2001; Miller, Bersoff, \& Harwood, 1990; Shweder, Mahapatra, \& Miller, 1990). The traditional approach to morality does not take into consideration the various relevant community values related to interdependence or collectivism (e.g., in Confucianism, Buddhism, or Hinduism). Also, notions of independence from formal behavioral rules do not apply in cultures where the fulfillment of one's duties is the most important moral purpose (Mishra, 2012; Saraswathi et al., 2011). Here, moral behavior implies accepting one's duties and obeying rules in everyday behavior (e.g., diet, communication among family and nonfamily members). Obedience to rules and to authorities, which differ in different cultural contexts, serves as a moral principle. Transgressions can evoke moral emotional responses, with guilt following private transgressions or shame following publicly exposed transgressions.

Recent theorizing on moral psychology focusing on the role of culture enables the integration of cognitive, emotional, and social aspects of moral purpose (e.g., Haidt, 2007; Jensen, 2011, 2012; Rai \& Fiske, 2011). The theoretical source of these approaches is the work by Shweder and colleagues (Shweder et al., 1990; Shweder, Much, Mahapatra, \& Park, 1997) suggesting a tripartite distinction of three ethics and the moral motives related to these three aspects, with differences within and across cultures. The ethic of autonomy focuses on the interests and rights of people as individuals, moral goals of the ethic of community centers on the person's duties and obligations to others, and the ethic of divinity follows the moral pursuit of connecting with the divine. The three ethics have their roots in the Old Testament (Ten Commandments).

A shortcoming of these culture-informed approaches is the neglect of developmental issues. Therefore, Jensen (2008) discusses a cultural perspective on the development of morality. Starting from a critical evaluation of the traditional cognitive-developmental approach to morality, which ignores cultural values and worldviews pertaining to spirituality, religion, or divinity, Jensen suggests a template model extending Shweder et al.'s (1997) notions of autonomy, community, and divinity. The moral concepts may be related to each other. For example, a community-based morality may be fueled by spirituality, fulfilling adolescents' needs for security and belonging while not threatening their autonomy.

According to Rothbaum and Trommsdorff (2007), the value of autonomy and interdependence may coexist, although the relationship between both depends on the cultural meaning of autonomy and relatedness. Referring to our previous example on parenting, adolescents may experience parental influence as aversive in the case in which their self-construal as an autonomous person is threatened. This would also threaten a positive (trusting) relationship with their parents. However, when adolescents experience parental influence as indicating a close interpersonal relationship, this would foster the belief in assurance and belonging. This is in line with the moral concept of community inducing compliance. Accordingly, compliance based on relatedness can indicate adolescents' agency (see also Miller, this volume; Trommsdorff, 2012a).

Jensen distinguishes between the degree and the types of moral concepts that persons of different ages use within an ethic. For example, in adolescence, the salience of peers and collective social contexts (e.g., school, work) may increase, shifting community concepts more to nonfamilial groups and broader social entities, at least in individualistic cultural contexts valuing autonomy. Research is needed to test if a developmental process observed in individualistic cultures is also valid in cultures where ingroup norms and values of interdependence prevail. In cultural contexts valuing relatedness, community concepts are instead confined to the family and ingroup. Our own stud ies on preschool children from Indonesia show less 
prosocial behavior toward strangers than in Israeli or German children (Trommsdorff, Friedlmeier, \& Mayer, 2007). It can be assumed that family values of emotional interdependence affect community concepts in cultures where values of relatedness prevail throughout development, thereby promoting a stricter difference between ingroup and outgroup.

Whether a community-oriented morality takes into account the perspective and interests of others beyond simply following the criteria of norm-based duty and social rules is an open question. At least, the reviewed studies on family values of interdependence (Trommsdorff \& Mayer, 2012) or our studies on emotion regulation of Indian, Japanese, and German children (Trommsdorff, 2012a) suggest that both ways are possible, depending on the cultural values. A further question is whose perspective is taken into account and whether "community" is defined as consisting of ingroup members only, or if ingroup and outgroup members are seen part of the "community." This brings us back to the main question of this chapter: how far do values and morals integrate self- and other orientation during adolescent development in a cultural context?

\section{Religious Purpose}

Morality serves to integrate social groups, constrain individuals, and join them together: "Morality binds and builds" (Haidt, 2007). Similarly, the central role of religion can be seen in the formation and integration of communities (Durkheim, 1915/1965): religions provide a system of beliefs and practices related to the sacred and unite believers into a moral community. In early theorizing on the psychology of religion, William James (1901/1997) assumed that religion is based on the emotions of individuals who experience a relationship with the divine. Although social anthropology provides functional, structural, and psychoanalytical explanations for religion including rituals and beliefs (Barnard, 2012), religious beliefs have also been related to the development of cultures (Kornadt, 2012) and the evolution of mind and societies (Atran \& Henrich, 2010; Norenzayan $\&$ Shariff, 2008).

Religions focus on the sacred as part of the natural and supernatural worlds, regulating interpersonal interactions and relationships between individuals and the sacred. Comparative studies have shown that polytheism, monotheism (e.g., Judaism, Christianity, and Islam), animism, totemism, and shamanism all have strict rules and rituals (e.g., including taboos regarding food) and often require obedience to an authority. In Hinduism, beliefs about the sacred are assumed to be a part of one's self- and worldview informing values and moral purpose (e.g., Mishra, 2013; Saraswathi et al., 2011). However, morality is not necessarily tied to religion. According to anthropological studies in small-scale societies, the gods want rituals but have limited moral concern over how people interact (for an overview, see Norenzayan, 2014). In larger, more complex societies, the belief in a "Big God" has emerged, organizing cooperation and prosocial behavior (even toward strangers): "religion's role in regulating moral affairs in large societies has been a cultural process that coalesced over time, primarily where anonymous societies took shape and expanded" (Norenzayan, 2014, p. 18). From an evolutionary perspective, religion has been seen as providing a system to suppress selfish behavior and increase group orientation (Norenzayan \& Shariff, 2008). Another important source for religious orientation may be the experience of death. In several cultures, biological conceptions of death are supplemented with religious conceptions, focusing on a new beginning in the afterlife, the soul, and supernatural entities (De Cruz, 2013; Huang, Cheng, \& Zhu, 2013; Kornadt, 2012; Roazzi, Nyhof, \& Johnson, 2013). In line with the saying "morality binds and blinds," recent research has focused on the harmful effects of religion in addition to the positive.

So far, there has been a lack of culturepsychological studies on religion in general and on the role of religiosity in adolescents' self- and worldviews in particular. An exception is Jensen's (2009) study on conceptions of God and the Devil based on interviews with children, adolescents, and adults. This work shows that these conceptions address issues related to purpose in life and the nature of good and evil. Taking a developmental and motivational approach that includes the role of culture and values may lead to a better understanding of adolescents' religiosity. Religiosity is a multidimensional phenomenon including several aspects of religious commitment (e.g., frequency of practicing religious rituals such as prayer, etc.), subjectively felt religiosity (strength of belief), and the perceived role of religiosity (e.g., for moral behavior, positive emotions, coping; e.g., Emmons, 2005). Adolescence is a period of heightened awareness and search for meaning and values with which to identify. Values are motivating factors, especially 
when they are closely related to moral and religious purpose or even considered "sacred" values (Ginges \& Atran, 2011; Weber, 1958). Religious purpose and beliefs are related to adolescents' development of values and moral orientation (e.g., "ethics of divinity") when they serve the search for meaning and self-identity as part of adolescents' self- and worldviews. Accordingly, adolescents tend to search for religious beliefs tied to moral values as guiding orientations in the development of their self- and worldviews.

Psychological studies on adolescents' religious purpose have recently increased, partly due to a rise of religious fundamentalism and a heightened spiritual awareness among adolescents (Roelkepartain, King, Wagener, \& Benson, 2005). However, the various kinds of religions (e.g., monotheism, syncretism, pantheism) and their varying values and moral beliefs have seldom been taken into account in studies on adolescent religiosity. For example, whereas Christians, Jews, and Muslims believe in a personal God's distinct identity, according to Shinto, God exists in various phenomena of nature. Hindu belief also recognizes various gods who differ in their roles and characters. Whereas Christianity, Judaism, and Islam are characterized by specific (more or less abstract) moral principles, Shinto is rather vague. The Shinto or Hindu observer focuses on practical activities and rituals in daily life as a path to supernatural agency.

The rise of new forms of spirituality is thought to be relevant for positive youth development (King \& Roeser, 2009). Positive effects of spirituality (e.g., spiritual dimensions of transcendence and a daily relationship with the Divine) in fostering internalization of cultural values, adaptation to social roles, and focus on school achievement have been shown for adolescent development in India (Mishra, 2012).

Researchers have often reported a positive role of religiosity for adolescents from Western and non-Western cultures (e.g., Youniss, McLellan, \& Yates, 1999). For example, religiosity was related to better academic achievement and fewer risky behaviors in African-American students (Abar, Carter, \& Winsler, 2009). French, Eisenberg, Purwono, and Sallquist (2012) showed positive effects of religious orientation on social development in Indonesian Muslim youth in Java. Culture and religion were related to the development of a self-protective future orientation in Israeli Palestinian adolescent (Seginer \& Mahajna, 2012). Pearce and Hardie (2012) demonstrated a positive role of religiosity in career orientation of US adolescent girls. Bond and colleagues (2012) reported positive effects of religion on the life satisfaction of adolescents in different cultures. Shannon, Oakes, Scheers, Richardson, and Stills (2013) demonstrated a significant association between spirituality (beliefs and experiences) and life satisfaction for at-risk (exposed to violence) urban African-American adolescents. Furthermore, prosocial aspects of religiosity and spirituality were related to the life satisfaction of Korean adolescents (Kim, Miles-Mason, Kim, \& Esquivel, 2013).

One explanation for the positive effects of religiosity may be that religiosity provides meaning and fulfills needs for belonging and autonomy. For example, the development of moral and religious purpose has been shown to be related to European-American adolescents' need for attachment (Granqvist, 2012). When God is seen as an attachment figure, attachment to God may satisfy adolescents' needs for belonging and autonomy, possibly partly compensating for experiencing insufficient social support and success. However, the role of attachment and autonomy for religious purpose in other cultural contexts and for non-monotheistic religions is not yet well understood and needs further research. Depending on the cultural context, adolescents may be less inclined to fulfill their need for belonging and relatedness by attachment to a benevolent and mighty God since their need is fulfilled by the family and ingroup. Instead, the monitoring function of God (one mighty God or various specific gods) in defining morals and rules for interpersonal behavior may be more relevant for them. Other adolescents experiencing low self-efficacy and restricted agency may delegate "control" to God and religious institutions, thus bolstering their self-esteem. Also, participating in religious groups may fulfill the need for belonging and agency, as suggested by studies on American adolescents (Smith, 2011).

Most studies suggest that religion and religiosity are positively associated with moral purpose and adolescents' social development. However, when needs for relatedness and autonomy are fulfilled by religiosity, does this necessarily imply positive developmental outcomes? For example, Eisenberg, Castellani, Panerai, Eggum, Cohen, Pastorelli, \& Caprara (2011) discuss how changes in religiousness would relate to developmental outcomes; the authors identified individual differences in the development of religious coping. Johnson, Li, Cohen, and Okun (2013) and Kornadt (2012) 
show that different concepts of God affect different kinds of social behavior. A concept of God as authoritarian (controlling, punishing) or benevolent (forgiving, protecting) induces more aggressive or more prosocial behavior in believers, respectively. Negative effects of religiosity, such as violence and antisocial behavior, resulting from social identity processes in specific groups cannot be ignored (Ysseldyk, Matheson, \& Anisman, 2010). Recent acts of terrorism (e.g., Boston Marathon attack) suggest that attachment to a Big God and belonging to a religious group may satisfy a need for power and, under certain conditions, may evoke violent aggression against nonbelievers.

Furthermore, it can be assumed that adolescents' religious values and related moral behavior support individual or relational agency, depending on their self- and worldview and the respective cultural context.

\section{Relations Among Values, Morals, and Religious Orientations}

To date, research on values, morals, and religious purpose in adolescent development has focused on only one or two of these phenomena and has usually ignored the role of culture. Some studies have discussed selected relations (e.g., among values and morality, values and religiosity, or morality and religiosity). For example, relations between values and religiosity were discussed by Rokeach (1969) and in the meta-analysis by Saroglou, Delpierre, and Dernelle (2004) based on Schwartz's model. Trommsdorff and Chen (2012) included several culture-informed contributions on the roles of values and religion in adolescent adjustment (e.g., Bond et al., 2012; French et al., 2012; Knafo, Daniel, Gabay, Zilber, \& Shir, 2012; Kornadt, 2012; Mayer \& Trommsdorff, 2012; Mishra, 2012; Pearce \& Hardie, 2012; Saroglou, 2012; Schwartz, 2012; Seginer \& Mahajna, 2012; Trommsdorff, 2012b). However, the interrelations among all three—values, morals, and religious purpose-were not explicitly studied in that volume because this was not its main topic. I would suggest that self- and worldviews function as generalized beliefs about the self, others, and the social, physical, and spiritual worlds. These generalized beliefs are shaped by the cultural context and interrelate all three-values, morals, and religious purposeas aspects of the cultural context.

In their study on minority groups of Jewish late adolescents in Belgium, Saraglou and Hanique (2006) investigated the influence of religion and values on Jewish and other collective identities. Adolescents shifting from a Jewish identity to a Belgian or to a transnational identity were less religious and had less traditional values. In a cross-cultural study on religiosity of adolescents (based on data from the VOC Study), family values, especially interdependence, mediated positive effects of religiosity on optimism and subjective well-being (Sabatier, Mayer, Friedlmeier, Lubiewska, \& Trommsdorff, 2011). Furthermore, Mayer and Trommsdorff (2012) have shown different cross-cultural relations among family values and religious orientations in individual- and culture-level studies. These and other studies show that similarities between family values and religious orientation of the mainstream society are associated with adolescents' well-being, thus supporting theories of cultural fit (Fulmer et al., 2010; Higgins, 2012; Oishi, 2000) and predicting positive developmental effects when individual and cultural values match.

Chinese adolescents do not consider religion to be important, and atheism is the official state belief in modern China. However, traditional Confucian values of filial piety are strongly related to adolescents' moral purpose of obedience and indebtedness to parents. The Confucian example thus indicates that "taboo" values such as filial piety are affecting moral purpose without being explicitly related to religion. In a similar way, in many Western secular societies, values of intergenerational solidarity are the basis for parental support. In contrast, in various other cultures, family values and related moral purpose (including ritualized filial duties to parents and ancestors) are fostered by spiritual beliefs in the other world. Family values and related moral and religious purpose encompass the past, present, and the future, for example, connecting the individual person and the (powerful) ancestors.

Furthermore, interrelations among values, moral purpose, and spirituality can be observed in nonsecular cultures such as India. Mishra (2012) explains how Hindu values are related to religious beliefs and the respective religious and moral socialization. In his study on the Hindu worldview, Mishra (2013) claims that religious and spiritual pursuits cannot be separated from each other; furthermore, morality is not possible without self-transcendence based on spiritual development. Moksha, one of the Hindu worldviews, affects social behavior and positive interpersonal and intergroup relationships. Through moksha, the attainment of one's true, basically good self is possible, thus 
allowing for moral actions. Developing a sense of unity with others overcomes boundaries between the self and others, in line with the belief that God and our true self are one.

Religiosity is an important experience in adolescent development when providing fulfillment of basic needs. When religiosity is closely related to adolescents' values and moral purpose as part of their self- and worldviews, strong motivational dynamics can be expected, depending on the cultural context and situational constellations. For example, intergroup conflicts associated with interreligious relations may arise for adolescents from immigrant families and ethnic minorities who face the problem of managing dominant cultural values and expectations that differ from those of their families (Verkuyten \& Martinovic, 2012). The perceived incompatibility between the values of the host or majority group and the minority's ethnoreligious community may induce frustrations due to adolescents' difficulties in building an identity. This may give rise to aggressive behavior directed toward the (majority) outgroup.

The need for group identity has been acknowledged in much research on adolescence. Moral commitment to the ingroup and related commitment to sacred values may function as the most powerful motivation for political violence when experiencing threat against one's ingroup (Ginges \& Atran, 2011; Ginges, Hansen, \& Norenzayan, 2009). Experiencing humiliation or loss of control and honor increases the solidarity of (religious or other social) groups. Violent reactions are perceived as legitimate, and terror activities are acknowledged as a noble struggle in the name of God (e.g., Putra \& Sukabdi, 2013). Perceived collective humiliation is the basis for nontraditional forms of group identity that fuel moral reasoning and the motivation to violently pursue sacred values, especially when values of masculine power prevail (Kornadt, 2012). In those cases in which religious purpose and sacred values are associated with ingroup identity and moral commitment to the ingroup, the probability for violent acts (e.g., "fighting to die for a cause") increases (Ginges \& Atran, 2011). The authors refer to case study interviews showing that most of the violent jihadis and suicide bombers adopted radical Islam in adolescence when the search for identity has high priority. When group identity is related to a collective sense of honor and the expectation of respect for the sacred values of one's ingroup, moral commitment as part of one's social identity can serve as the basis for collective action (Drury $\&$ Reicher, 2000). Sacred values may be related not only to religious but also to moral purpose. Here, adolescents' need for autonomy, relatedness, and competence can be assumed to be experienced as collective needs. In the case that one's own group's sacred values are not accepted or are even rejected by the outgroup (nonbelievers), moral outrage and political violence may result. For example, in 2006, two young Lebanese attempted a terrorist attack in two trains in Germany in order to kill a large number of "nonbelievers." One of the adolescent terrorists was reported to argue that terrorism was a justified reaction to the publication of the Mohammed paintings that he considered a criminal act (Emig, 2012).

As recent studies on sacred values, moral commitment, and group identity have shown, basic individual needs may be transformed by cultural and group dynamic processes into collective action. Accordingly, an extension of self-determination theory that includes cultural and social-psychological processes seems necessary to explain the moral outrage and violence of adolescents who are committed to fundamental religious beliefs. Furthermore, recent theories on social and relational morality discussing the relations among values, morality, and religiosity (Graham \& Haidt, 2012; Haidt, 2007; Rai \& Fiske, 2011) should be extended to questions of development in adolescence. When religious group identification and related strict ingroup norms are related to a moral (sacred) worldview, the associations among religiosity, moral purpose, and values intensify. This may be especially the case in adolescence when individuals are searching for purpose in life, for autonomy, and relatedness.

A recent example is the transformation of a German adolescent, Eric Breininger, into a radical Islamist related to the "Sauerland-Gruppe". He was killed in Waziristan by soldiers from Pakistan. Before his death, he described this act as his way to paradise (Ghaffar al-Almani, 2009). His writing showed that he was searching for meaning, experiencing a major crisis, and suffering from various difficult exercises after a religious Muslim convinced him to become a Muslim himself. As a result of his further very rapid radicalization, he finally left for a terrorist training camp of the Islamic Dschihad-Union in Pakistan. There, he suffered from physical pain during the tough training and from social isolation due to little Arab language proficiency and the loss of two of his Muslim 
"brothers." However, he felt a moral obligation that his way to paradise had to include such personal sacrifices and also the death of the "nonbelievers." His harsh self-discipline and self-imposed psychological and physical suffering can be seen as indicators for secondary control; however, they were instrumental in his achieving primary control: the killing of nonbelievers on his "way to paradise."

Moral values can transform into sacred, absolute, and even transcendent values, as this example and as Ginges and Atran (2011) have shown. Adolescents may engage in political acts of violent extremism and self-sacrifice motivated by dynamics of "sacred values" and moral commitment (Kornadt, 2012). In certain sociocultural settings, a combination of certain values and moral intuitions may constitute a self- and worldview that "binds and blinds." This process may indicate the role of situational strength affecting the roles played by values, morals, and religious purpose in adolescents' development.

\section{Conclusion and Outlook}

Values, morals, and religious purpose are interrelated as crucial components of adolescents' self- and world views that provide meaning and orientation. They are inextricably intertwined with the respective cultural context through socialization processes. Abstract conceptions of cultural values do not reveal their specific functions unless the respective sociocultural context is taken into account. For example, social orientations may be functional in both egalitarian as well as hierarchical structures. Or, individualism may function well when combined with social orientation or interdependence. Therefore, the cultural and individual levels of analyses have to be distinguished and possibly integrated by multilevel methods.

The cultural model of relative independence and interdependence, the culture's relatively tight or loose structure, the respective situational strength, and the adolescents' social position, socialization experience, and personality all contribute to shaping adolescents' agency and fostering their self- and worldviews. Culture-specific socialization functions through social interactions between adolescents and their parents, peers, and other adults in more or less tightly structured and regulated social situations. Accordingly, adolescents' individual agency focuses on selecting goals in accordance with their self- and worldviews. Beyond the sociocultural context, and beyond individual needs of autonomy, competence, and relatedness, adolescents' agency is shaped by collective needs of social identity.

Individual and collective agency, fueled by self-regulation, constitutes adolescents' agentic development. Therefore, from a culture-informed perspective, simply contrasting autonomy and relatedness and independent and interdependent values is misleading. It is instead assumed that both autonomy and relatedness have different functions: for example, autonomy aiming for independence or autonomy aiming at self-endorsement accommodating to social expectations (Chen, Vansteenkiste, Beyers, Soenens, \& Van Petegem, 2013). The different functions of relatedness, as suggested by Rothbaum and Trommsdorff (2007), have pointed to the culture-specific function of relatedness as balancing autonomy in the search for trust (between independent individuals) and relatedness as resulting from a belief in assurance (between interdependent individuals).

Self-regulation serving to reach individual or collective goals in the face of difficulties and over time can be promoted by adhering to specific values, morals, and religious purpose. The type of self-regulation that is used depends on self- and worldviews (malleable vs. entity) (Dweck, 1999) and is based on control beliefs (e.g., primary, secondary, harmony control) (Morling \& Evered, 2006; Seginer, Trommsdorff, \& Essau, 1993; Weisz, Rothbaum, \& Blackburn, 1984), the relative preference for approach/promotion- or avoidancel prevention-focused goals (Higgins, 2012), and on cultural models of independence or interdependence (Markus \& Kitayama, 1991). Self-regulation is shaped by situational affordances and constraints and guides culturally adaptive behavior in adolescents' development (Trommsdorff, 2009a; 2012a).

The interrelations among values, morality, and religiosity are therefore manifest in adolescents' self- and worldviews and their related preferences for self-regulation and control. For example, when experiencing diminished personal control, adolescents may prefer to shift control expectations to supernatural beings (God) or powerful others (e.g., closely knit social groups). Such belief in powerful agents may foster values of obedience and conformity to the respective authority and result in social movements based in religion and peaceful activities (e.g., Gandhi, Martin Luther King) or result in civil disobedience, violence, or terrorism. When adolescents are motivated to align with the (powerful) agent's expectations, their need for autonomy, competence, and relatedness can be fulfilled. This 
process may promote the agentic pursuit of "sacred" values, intertwining morality with religion.

Interrelations among values, morality, and religious purpose depend on the fulfillment of the basic individual needs of autonomy, competence, and relatedness (see also the need to belong and to fit in: Baumeister \& Leary, 1995; Over \& Carpenter, 2013). However, these individual needs may be transformed into collective needs depending on the given situation and cultural context and the strength of normative rules. Accordingly, the need to achieve collective autonomy, competence, and relatedness may induce adolescents to conform to group norms, imitate role models, and integrate group-oriented values and religious and moral beliefs as part of their individual self- and worldviews.

Therefore, it is suggested that we extend our focus on the developmental and social-psychological processes of person-environment interactions (e.g., specified by relational models and culture-informed situational strength theory). Consequently, the discussion on adolescents' development of values, morals, and religious purpose should be taking into account both individual and collective self- and worldviews.

This extension broadens the perspective beyond the mainstream of psychological studies on adolescence, which have neglected the vast and diverse majority of the world's population and ongoing sociocultural changes. For example, in the future, adolescents will encounter multiple cultures and will have to adapt to changing interrelations between tradition and modernity, stability and change, autonomy and relatedness.

To date, the assumed dynamics of the cultural mechanisms that shape adolescents' values, morals, and religious purposes have been discussed as components of their self- and worldviews. However, the substance of those mechanisms as part of person-environment interactions in relation to adolescents' developmental and situational resources and constraints remains to be studied in more detail. Furthermore, the role of culture, situations, and norms in the development of values, morals, and religious purpose also needs more empirical research.

In future research, cultural and individual differences in the transmission processes of values, morals, and religious purpose have to be taken into account (e.g., Knafo et al., 2012; Knafo \& Schwartz, 2009; Trommsdorff, 2009b). Here, the role of tightness of norms in the transmission process has to be studied in more detail. Although normative socialization is an essential aspect of children's and adolescents' development of values, morals, and religious purpose in all cultures, cultures differ how they prioritize the strictness and contents of certain norms and practices, as well as the strictness of sanctions when individuals do not conform to these norms. Cultural socialization therefore differs regarding the tightness or looseness of norms and how these norms are transmitted.

In loose, secular cultures, for example, religion is usually practiced only on specific occasions, whereas in nonsecularized cultures, religious and spiritual traditions function as cultural entities and are performed and transmitted through practice in everyday life (Belzen, 2010). Therefore, in traditional societies, moral development is closely related and intertwined with religious development. Rai and Fiske (2011) suggest that for many people across various cultures "morality is religion" (p. 67). In these societies, agents of socialization refrain from verbal explanations of moral and religious principles and instead rely on sharing moral and religious practices through rituals in the family and community. In traditional societies, values and religious and spiritual rituals are practiced and experienced in everyday social activities; these function as major transmission belts for adolescents' development of values, morals, and religious purpose. This process refers to the assumed universal motivation to follow the conventional norms, which are expressed in social activities and ritualized behavior (e.g., for Java or India see Mishra, 2012; Mulder, 1996; Shweder et al., 1997).

In Western, secularized societies, the socialization of values, morals, and religious beliefs is based on argumentative reasoning and explanations of general models, the Zeitgeist, or abstract moral principles. By contrast, in traditional, non-Western societies, value transmission and the transmission of moral and religious purpose is based on the fulfillment of clearly defined, concrete duties in everyday life. These duties involve various rituals and daily practices that structure adolescents' developmental tasks and regulate their everyday behavior as part of normative socialization processes. Thereby, children and adolescents receive concrete information about adequate situation-specific behavior, enabling the development of realistic goal setting and early self-regulation abilities that foster the development of cultural fit in close cooperation with adults and peers. Adolescents may have to choose among cultural tasks by referring to individual and/or collective agency. 
Universal and culturally specific processes influence adolescents' development of values, morals, and religious purpose, which are embedded in the cultural context. Although Brewer and Chen (2007) suggest that cultures provide answers to questions about the self, the world, and goals to which one should aspire, these answers probably lack clarity and consistency and may have multiple interpretations in "open" or "loose" cultures where heterogeneity and ongoing changes prevail, thus undermining the strength of the situation. Accordingly, adolescents may have to choose among cultural tasks and answers and their respective meaning. Thus, adolescents regulate their individual development by integrating values, morals, and religious orientations in line with their self- and world-views by referring to individual and/or collective agency to achieve an optimal cultural fit.

\section{Acknowledgments}

This research was supported by the German Research Foundation (DFG GZ, TR 169/143) as part of the Research Group "Limits of intentionality." I am grateful to Hans-Joachim Kornadt and Rachel Seginer for their valuable comments, especially for Rachel's reference to the Old Testament and for providing narratives from Israeli girls. I thank Holly Bunje for her careful editing.

\section{References}

Abar, B., Carter, K. L., \& Winsler, A. (2009). The effects of maternal parenting style and religious commitment on self-regulation, academic achievement, and risk behavior among African-American parochial college students. Journal of Adolescence, 32, 259-273. doi: http://dx.doi. org/10.1016/j.adolescence.2008.03.008

Arnett, J. J. (2006). Emerging adulthood. The winding road from the late teens through the twenties. Oxford, UK: Oxford University Press.

Arnett, J. J. (Ed.). (2012). Adolescent psychology around the world. New York: Psychology Press.

Arnett, J. J., \& Eisenberg, N. (2007). Introduction to the special section: Emerging adulthood around the world. Child Development Perspectives, 1, 66-67. doi: 10.1111/j.1750-8606.2007.00015.x

Atran, S., \& Henrich, J. (2010). The evolution of religion: How cognitive by-products, adaptive learning heuristics, ritual displays, and group competition generate deep commitments to prosocial religions. Biological Theory, 5, 18-30.

Barnard, A. (2012). Genesis of symbolic thought. New York: Cambridge University Press.

Baumeister, R. F., \& Leary, M. R. (1995). The need to belong: Desire for interpersonal attachments as a fundamental human motivation. Psychological Bulletin, 117, 497-529. doi: 10.1037/0033-2909.117.3.497
Belzen, J. A. (2010). Towards cultural psychology of religion: Principles, approaches, applications. New York: Springer.

Blasi, A. (1993). The development of identity: Some implications for moral functioning. In G. G. Noam \& T. E. Wren (Eds.), The moral self (pp. 99-122). New Baskerville, MA: MIT Press.

Bond, M. H., Lun, V. M.-C., \& Li, L. M. W. (2012). The role of secularism in values and engagement in religious practices for the life satisfaction of young people: The moderating role of national-societal factors. In G. Trommsdorff $\&$ X. Chen (Eds.), Values, religion, and culture in adolescent development (pp. 123-145). New York: Cambridge University Press.

Bontempo, R., Lobel, S., \& Triandis, H. (1990). Compliance and value internalization in Brazil and the US: Effects of allocentrism and anonymity. Journal of Cross-Cultural Psychology, 21, 200-213. 10.1177/0022022190212004.

Brewer, M. B., \& Chen, Y.-R. (2007). Where (who) are collectives in collectivism? Toward conceptual clarification of individualism and collectivism. Psychological Review, 114, 133-151. doi: 10.1037/0033-295x.114.1.133

Bronfenbrenner, U. (1979). The ecology of human development: Experiments by nature and design. Cambridge, MA: Harvard University Press.

Brown, B. B., Larson, R. W., \& Saraswathi, T. S. (Eds.). (2002). The world's youth: Adolescence in eight regions of the globe. New York: Cambridge University Press.

Bruner, J. S. (1990). Culture and human development: A new look. Human Development, 33, 344-355. doi: $10.1159 / 000276535$

Chao, R., \& Tseng, V. (2002). Parenting of Asians. In M. H Bornstein (Ed.), Handbook of parenting: Vol. 4. Social conditions and applied parenting (2nd ed., pp. 59-93). Mahwah, NJ: Erlbaum.

Cheah, C. S. L., Bayram Özdemir, S., \& Leung, C. Y. Y. (2012). Predicting the filial behaviors of Chinese-Malaysian adolescents from perceived parental investments, filial emotions, and parental warmth and support. Journal of Adolescence, 35, 628-637. doi: http://dx.doi.org/10.1016/j. adolescence.2011.07.001

Chen, B., Vansteenkiste, M., Beyers, W., Soenens, B., \& Van Petegem, S. (2013). Autonomy in family decision making for Chinese adolescents: Disentangling the dual meaning of autonomy. Journal of Cross-Cultural Psychology, 44, 1184-1209.

Chen, X., Wang, L., \& Liu, J. (2012). Adolescent cultural values and adjustment in the changing Chinese society. In G. Trommsdorff \& X. Chen (Eds.), Values, religion, and culture in adolescent development (pp. 235-270). Cambridge, UK: Cambridge University Press.

Cheung, C.-K., Lee, J.-J., \& Chan, C.-M. (1994) Explicating filial piety in relation to family cohesion. Journal of Social Behavior \& Personality, 9, 565-580. doi: 10.1111/1467-9280.00409

Cohen, D., \& Gunz, A. (2002). As seen by the other .... Perspectives on the self in the memories and emotional perceptions of Easterners and Westerners. Psychological Science, 13, 55-59. doi: 10.1111/1467-9280.00409

Cole, M., \& Packer, M. (2011). Culture in development. In M. H. Bornstein \& M. E. Lamb (Eds.), Developmental science: An advanced textbook (6 ed., pp. 51-108). New York: Psychology Press. 
Collins, W. A., \& Steinberg, L. (2006). Adolescent development in interpersonal context. In N. Eisenberg, W. Damon, \& R. M. Lerner (Eds.), Handbook of child psychology: Social, emotional, and personality development (6 ed., vol. 3, pp. 1003-1067). Hoboken, NJ: Wiley.

De Cruz, H. (2013). Religious concepts as structured imagination. International Journal for the Psychology of Religion, 23 , 63-74. doi: 10.1080/10508619.2013.735495

Doi, T. (1973). The anatomy of dependence. Oxford, UK: Kodansha International.

Drury, J., \& Reicher, S. (2000). Collective action and psychological change: The emergence of new social identities. British Journal of Social Psychology, 39, 579-604. doi: $10.1348 / 014466600164642$

Durkheim, E. (1915/1995). The elementary forms of the religious life: A study in religious sociology: London: George Allen \& Unwin.

Dweck, C. S. (1999). Self-theories: Their role in motivation, personality, and development. Philadelphia: Psychology Press.

Eisenberg, N., Morris, A. S., McDaniel, B., \& Spinrad, T. L. (2009). Moral cognitions and prosocial responding in adolescence. Handbook of Adolescent Psychology. New York: Wiley.

Eisenberg, N., Castellani, V., Panerai, L., Eggum, N. D. Cohen, A. B., Pastorelli, C., \& Caprara, G. V. (2011). Trajectories of religious coping from adolescence into early adulthood: Their form and relations to externalizing problems and prosocial behavior. Journal of Personality. 79, 841-873. doi: 10.1111/j.1467-6494.2011.00703.x

Eisenberg, N., \& Silver, R. C. (2011). Growing up in the shadow of terrorism: Youth in America after 9/11. American Psychologist, 66, 468-481. doi: 10.1037/a0024619

Emig, J. (2012). Möglichkeiten der Früherkennung islamischer Radikalisierungsprozesse [Possibilities for early detection of Islamistic radicalization processes]. In Landespolizeischule-Rheinland-Pfalz,LandeskriminalamtRheinland-Pfalz, \& Volkswagen-Stiftung (Eds.), Radikalisierungsmechanismen und Deradikalisierungsstrategien bei der Bekämpfung des islamischen Terrorismus im europäischen Vergleich (pp. 51-61). Hilden, GER.: Verlag Deutsche Polizeiliteratur.

Emmons, R.A. (2005). Striving for the sacred: Personal goals, life meaning, and religion. Journal of Social Issues, 61, 731-745. doi: $10.1111 / j .1540-4560.2005 .00429 . x$

French, D. C., Eisenberg, N., Purwono, U., \& Sallquist, J. A. (2012). Indonesian Muslim adolescents and the ecology of religion. In G. Trommsdorff \& X. Chen (Eds.), Values, religion, and culture in adolescent development (pp. 146-163). New York: Cambridge University Press.

Fuligni, A. J. (1998). Authority, autonomy, and parentadolescent conflict and cohesion: A study of adolescents from Mexican, Chinese, Filipino, and European backgrounds. Developmental Psychology, 34, 782-792. doi: $10.1037 / 0012-1649.34 .4 .782$

Fuligni, A. J., \& Zhang, W. (2004). Attitudes toward family obligation among adolescents in contemporary urban and rural China. Child Development, 75, 180-192. doi: 10.1111/j.1467-8624.2004.00662.x

Fulmer, C. A., Gelfand, M. J., Kruglanski, A. W., Kim-Prieto, C., Diener, E., Pierro, A., \& Higgins, E. T. (2010). On "feeling right" in cultural contexts: How person-culture match affects self-esteem and subjective well-being. Psychological Science, 21, 1563-1569. doi: 10.1177/0956797610384742
Gelfand, M. J., Raver, J. L., Nishii, L., Leslie, L. A., Lun, J., Lim, B. C., ... Yamaguchi, S. (2011). Differences between tight and loose cultures: A 33-nation study. Science, 332, 1100-1104. doi: 10.1126/science.1197754

Ghaffar al-Almani, A. (2009). Mein Weg nach Jannah. Scribd. com. Retrieved 27.5.2014, from http://de.scribd.com/ doc/31071994/Schaheed-Abdul-Ghaffar-al-Almani-MeinWeg-Nach-Jannah

Gibbs, J. C., Basinger, K. S., Grime, R. L., \& Snarey, J. R. (2007). Moral judgment development across cultures: Revisiting Kohlberg's universality claims. Developmental Review, 27, 443-500. doi: http://dx.doi.org/10.1016/j. dr.2007.04.001

Ginges, J., \& Atran, S. (2011). War as a moral imperative (not just politics by other means). Proceedings of the Royal Society B, 278, 2930-2938. doi: 10.1098/rspb.2010.2384

Ginges, J., Hansen, I., \& Norenzayan, A. (2009). Religion and support for suicide attacks. Psychological Science, 20, 224-230. doi: 10.1111/j.1467-9280.2009.02270.x

Graham, J., \& Haidt, J. (2012). Sacred values and evil adversaries: A moral foundations approach. In M. Mikulincer \& P. R. Shaver (Eds.), The social psychology of morality: Exploring the causes of good and evil. (pp. 11-31). Washington, DC: American Psychological Association.

Granqvist, P. (2012). Attachment and religious development in adolescence: The implications of culture. In G. Trommsdorff \& X. Chen (Eds.), Values, religion, and culture in adolescent development (pp. 315-340). New York: Cambridge University Press.

Haidt, J. (2007). The new synthesis in moral psychology. Science, 316, 998-1002. doi: 10.1126/science. 1137651

Heckhausen, J. (2002). Developmental regulation of lifecourse transitions: A control theory approach. In L. Pulkkinen \& A. Caspi (Eds.), Paths to successfuldevelopment: Personality in the life course (pp. 257-280). New York: Cambridge University Press.

Hepper, E. G., Sedikides, C., \& Cai, H. (2013). Selfenhancement and self-protection strategies in China: Cultural expressions of a fundamental human motive. Journal of Cross-Cultural Psychology, 44, 5-23. doi: $10.1177 / 0022022111428515$

Higgins, E. T. (2012). Beyond pleasure and pain. Oxford, UK: Oxford University Press.

Huang, J., Cheng, L., \& Zhu, J. (2013). Intuitive conceptions of dead persons' mentality: A cross-cultural replication and more. International Journal for the Psychology of Religion, 23, 29-41. doi: 10.1080/10508619.2013.735493

James, W. (1901/1997). Die Vielfalt religiöser Erfahrung [The varieties of religious experience]. Berlin: Insel.

Jensen, L. A. (2008). Through two lenses: A cultural-developmental approach to moral psychology. Developmental Review, 28, 289-315. doi: Org/10.1016/j.dr.2007.11.001

Jensen, L. A. (2009). Conceptions of god and the devil across the lifespan: A cultural-developmental study of religious liberals and conservatives. Journal for the Scientific Study of Religion, 48, 121-145. doi: 10.1111/j.1468-5906.2009.01433.x

Jensen, L. A. (2011). The cultural-developmental theory of moral psychology: A new synthesis. In L. A. Jensen (Ed.), Bridging cultural and developmental approaches to psychology: New syntheses in theory, research, and policy (pp. 3-25). New York: Oxford University Press.

Jensen, L. A. (2012). Bridging universal and cultural perspectives: A vision for developmental psychology in a 
global world. Child Development Perspectives, 6, 98-104. doi: 10.1111/j.1750-8606.2011.00213.x

Johnson, K. A., Li, Y. J., Cohen, A. B., \& Okun, M. A. (2013). Friends in high places: The influence of authoritarian and benevolent god-concepts on social attitudes and behaviors. Psychology of Religion and Spirituality, 5, 15-22. doi: $10.1037 / a 0030138$

Kagitcibasi, C. (2007). Family, self, and buman development across cultures: Theory and application (2nd ed.). Mahwah, NJ: Erlbaum.

Kagitcibasi, C. (2012). Sociocultural change and integrative syntheses in human development: Autonomous-related self and social-cognitive competence. Child Development Perspectives, 6, 5-11. doi: $10.1111 / \mathrm{j} .1750-8606.2011 .00173 . \mathrm{x}$

Kasser, T. (2011). Cultural values and the well-being of future generations: A cross-national study. Journal of Cross-Cultural Psychology, 42, 206-215. doi: 10.1177/0022022110396865

Kim, S., Miles-Mason, E., Kim, C. Y., \& Esquivel, G. B. (2013). Religiosity/spirituality and life satisfaction in Korean American adolescents. Psychology of Religion and Spirituality, 5, 33-40. doi: 10.1037/a0030628

Kim, Y. -H., \& Tov, W. (2011). Cultural processes underlying subjective well-being. In A. K. -y. Leung, C. -y. Chiu, \& Y. -y. Hong (Eds.), Cultural processes: A social psychological perspective (pp. 154-171). New York: Cambridge University Press.

King, P. E., \& Roeser, R. W. (2009). Religion and spirituality in adolescent development. In R. M. Lerner \& L. Steinberg (Eds.), Handbook of adolescent psychology (3 ed., vol. 1, pp. 435-478). Hoboken, NJ: Wiley.

Kitayama, S., \& Imada, T. (2010). Implicit independence and interdependence: A cultural task analysis. In B. Mesquita, L. F. Barrett, \& E. R. Smith (Eds.), The mind in context. (pp. 174-200). New York: Guilford Press.

Knafo, A., Daniel, E., Gabay, S., Zilber, R., \& Shir, R. (2012). Religion and the intergenerational continuity of values. In G. Trommsdorff \& X. Chen (Eds.), Values, religion, and culture in adolescent development (pp. 370-390). New York: Cambridge University Press.

Knafo, A., \& Schwartz, S. H. (2009). Accounting for parentchild value congruence: Theoretical considerations and empirical evidence. In U. Schönpflug (Ed.), Cultural transmission: Psychological, developmental, social, and methodological aspects (pp. 240-268). Cambridge, UK: Cambridge University Press.

Kohlberg, L. (1984). Essays on moral development: Vol. 2. The psychology of moral development. San Francisco: Harper \& Row.

Kornadt, H. -J. (2012). Psychological functions of religion in youth-A historical and cultural perspective. In G. Trommsdorff \& X. Chen (Eds.), Values, religion, and culture in adolescent development (pp. 46-65). New York: Cambridge University Press.

Kuczinsky, L. (Ed.). (2002). Handbook of dynamics in parentchild relations. Thousand Oaks, CA: Sage.

Malti, T., \& Krettenauer, T. (2013). The relation of moral emotion attributions to prosocial and antisocial behavior: A meta-analysis. Child Development, 84, 397-412. doi: $10.1111 / \mathrm{j} .1467-8624.2012 .01851 . \mathrm{x}$

Markus, H. R., \& Kitayama, S. (1991). Culture and the self: Implications for cognition, emotion, and motivation. Psychological Review, 98, 224-253. doi: 10.1037/0033-295X.98.2.224
Markus, H. R., \& Kitayama, S. (2004). Models of agency: Sociocultural diversity in the construction of action. In V. Murphy-Berman \& J. Berman Lincoln (Eds.), The 49th Annual Nebraska Symposium on Motivation: Cross-cultural differences in perspectives on self (pp. 1-57). Lincoln: University of Nebraska Press.

Markus, H., \& Nurius, P. (1986). Possible selves. American Psychologist, 41, 954-969. doi: 10.1037/0003-066X.41.9.954

Mayer, B. (2013). Family change theory: A preliminary evaluation on the basis of recent cross-cultural studies. In I. Albert \& D. Ferring (Eds.), Intergenerational relations. European perspectives on family and society (pp. 167-187). Cambridge, UK: Policy Press.

Mayer, B., \& Trommsdorff, G. (2010). Adolescents' value of children and their intentions to have children: A cross-cultural and multilevel analysis. Journal of Cross-Cultural Psychology, 41, 671-689. doi: 10.1177/0022022110372195

Mayer, B., \& Trommsdorff, G. (2012). Cross-cultural perspectives on adolescents' religiosity and family orientation. In G. Trommsdorff \& X. Chen (Eds.), Values, religion, and culture in adolescent development (pp. 341369). New York: Cambridge University Press.

Mayer, B., Trommsdorff, G., Kagitcibasi, C., \& Mishra, R. C. (2012). Family models of independence/interdependence and their intergenerational similarity in Germany, Turkey, and India. Family Science, 3, 64-74. doi: 10.1080/194246 20.2011.671503

Miller, J. G. (1997). Cultural conceptions of duty: Implications for motivation and morality. In D. Munro, J. F. Schumaker, \& S. Carr (Eds.), Motivation and culture (pp. 178-192). New York: Routledge.

Miller, J. G. (2001). Culture and moral development. In D. Matsumoto (Ed.), The handbook of culture and psychology (pp. 151-169). Oxford, UK: Oxford University Press.

Miller, J. G., Bersoff, D. M., \& Harwood, R. L. (1990). Perceptions of social responsibilities in India and in the United States: Moral imperatives or personal decisions? Journal of Personality \& Social Psychology, 58, 33-47. doi: 10.1037/0022-3514.58.1.33

Mishra, R. C. (2012). Hindu religious values and their influence on youths in India. In G. Trommsdorff \& X. Chen (Eds.), Values, religion, and culture in adolescent development (pp. 424-442). New York: Cambridge University Press.

Mishra, R. C. (2013). Moksha and the Hindu worldview. Psychology and Developing Societies, 25, 21-42. doi: $10.1177 / 0971333613477318$

Morling, B., \& Evered, S. (2006). Secondary control reviewed and defined. Psychological Bulletin, 132, 269-296. doi: 10.1037/0033-2909.132.2.269

Mulder, N. (1996). Inside Indonesian society: Cultural change in Indonesia. Amsterdam: Pepin Press.

Norenzayan, A. (2014). Does religion make people moral? [Special issue]. Behaviour Evolved Morality: The Biology and Philosophy of Human Conscience.

Norenzayan, A., \& Shariff, A. F. (2008). The origin and evolution of religious prosociality. Science, 322, 58-62. doi: $10.1126 /$ science. 1158757

Oishi, S. (2000). Goals as cornerstones of subjective wellbeing: Linking individuals and cultures. In E. Diener $\&$ E. M. Suh (Eds.), Culture and subjective well being (pp. 87-112). Cambridge, MA: MIT Press. 
Over, H., \& Carpenter, M. (2013). The social side of imitation. Child Development Perspectives, 7, 6-11. doi: 10.1111/ cdep.12006

Oyserman, D., Coon, H. M., \& Kemmelmeier, M. (2002). Rethinking individualism and collectivism: Evaluation of theoretical assumptions and meta-analyses. Psychological Bulletin, 128, 3-72. doi: 10.1037/0033-2909.128.1.3

Pearce, L. D., \& Hardie, J. H. (2012). Religion's role in the development of girls' occupational aspirations. In G. Trommsdorff \& X. Chen (Eds.), Values, religion, and culture in adolescent development (pp. 271-289). New York: Cambridge University Press.

Putra, I. E., \& Sukabdi, Z. A. (2013). Basic concepts and reasons behind the emergence of religious terror activities in Indonesia: An inside view. Asian Journal of Social Psychology. doi: 10.1111/ajsp.12001

Rai, T. S., \& Fiske, A. P. (2011). Moral psychology is relationship regulation: Moral motives for unity, hierarchy, equality, and proportionality. Psychological Review, 118, 57-75. doi: $10.1037 / \mathrm{a} 0021867$

Roazzi, M., Nyhof, M., \& Johnson, C. (2013). Mind, soul and spirit: Conceptions of immaterial identity in different cultures. International Journal for the Psychology of Religion, 23, 75-86. doi: 10.1080/10508619.2013.735504

Roelkepartain, E. C., King, P. E., Wagener, L., \& Benson, P. L. (Eds.). (2005). The handbook of spiritual development in childhood and adolescence. Thousand Oaks, CA: Sage.

Rokeach, M. (1969). Values system and religion. Review of Religious Research, 11, 2-23. doi: 10.1111/j.1540-4560.2005.00430.x

Rothbart, M. K. (2011). Becoming who we are: Temperament and personality in development. New York: Guilford Press.

Rothbaum, F., Pott, M., Azuma, H., Miyake, K., \& Weisz, J. (2000). The development of close relationships in Japan and the United States: Paths of symbiotic harmony and generative tension. Child Development, 71, 1121-1142. doi: $10.1111 / 1467-8624.00214$

Rothbaum, F., \& Trommsdorff, G. (2007). Do roots and wings oppose or complement one another? The socialization of autonomy and relatedness in cultural context. In J. E. Grusec \& P. Hastings (Eds.), The handbook of socialization (pp. 461-489). New York: Guilford Press.

Rothbaum, F., \& Wang, Y. Z. (2010). Fostering the child's malleable views of the self and the world: Caregiving practices in East Asian and European-American communities. In B. Mayer \& H. -J. Kornadt (Eds.), Psychologie-KulturGesellschaft (pp. 101-120). Wiesbaden, GER: VS Verlag.

Rothbaum, F., \& Wang, Y. Z. (2011). Cultural and developmental pathways to acceptance or self and acceptance of the world. In L. A. Jensen (Ed.), Bridging cultural and developmental approaches to psychology: New syntheses in theory, research, and policy (pp. 187-211). New York: Oxford University Press.

Rothbaum, F., Wang, Z. Y., \& Cohen, D. (2012). Cultural differences in self-awareness and spirituality in adolescence: Pathways to self-transcendence. In G. Trommsdorff $\&$ X. Chen (Eds.), Values, religion, and culture in adolescent development (pp. 66-95). New York: Cambridge University Press.

Ryan, R. M., \& Deci, E. L. (2000). Self-determination theory and the facilitation of intrinsic motivation, social development, and well-being. American Psychologist, 55, 68-78. doi: 10.1037/0003-066X.55.1.68
Sabatier, C., Mayer, B., Friedlmeier, M., Lubiewska, K. \& Trommsdorff, G. (2011). Religiosity, family orienta tion, and life satisfaction of adolescents in four countries. Journal of Cross-Cultural Psychology, 42, 1375-1393. doi: $10.1177 / 0022022111412343$

Saraswathi, T. S., Mistry, J., \& Dutta, R. (2011). Reconceptualizing lifespan development through a Hindu perspective. In L. A. Jensen (Ed.), Bridging cultural and developmental approaches to psychology: New syntheses in theory, research, and policy (pp. 276-302). New York: Oxford University Press.

Saroglou, V. (2012). Adolescents' social development and the role of religion: Coherence at the detriment of openness. In G. Trommsdorff \& X. Chen (Eds.), Values, religion, and culture in adolescent development (pp. 391-423). New York: Cambridge University Press.

Saroglou, V., Delpierre, V., \& Dernelle, R. (2004). Values and religiosity: A meta-analysis of studies using Schwartz's model. Personality and Individual Differences, 37, 721-734. doi: 10.1016/j.paid.2003.10.005

Saroglou, V., \& Hanique, B. (2006). Jewish identity, values, and religion in a globalized world: A study of late adolescents. Identity: An International Journal of Theory and Research, 6, 231-249. doi: 10.1207/s1532706xid0603_2

Schwartz, S. H. (2011). Values: Cultural and individual. In F. J. R. Van de Vijver, A. Chasiotis, \& S. M. Breugelmans (Eds.), Fundamental questions in cross-cultural psychology (pp. 463-493). Cambridge, UK: Cambridge University Press.

Schwartz, S. H. (2012). Values and religion in adolescent development: Cross-national and comparative evidence. In G. Trommsdorff \& X. Chen (Eds.), Values, religion, and culture in adolescent development (pp. 97-122). New York: Cambridge University Press.

Schwarz, B., Mayer, B., Trommsdorff, G., Ben-Arieh, A. Friedlmeier, M., Lubiewska, K., . . Peltzer, K. (2012). Does the importance of parent and peer relationships for adolescents' life satisfaction vary across cultures? Journal of Early Adolescence, 32, 55-80. doi: 10.1177/0272431611419508

Schwarz, B., \& Trommsdorff, G. (2005). The relation between attachment and intergenerational support. European Journal of Ageing, 2, 192-199.

Seginer, R. (2009). Future orientation: Developmental and ecological perspectives. New York: Springer Science + Business Media.

Seginer, R., \& Mahajna, S. (2012). With God's help: The future orientation of Palestinian girls in Israel growing up Muslim. In G. Trommsdorff \& X. Chen (Eds.), Values, religion, and culture in adolescent development (pp. 253-270). New York: Cambridge University Press.

Seginer, R., Trommsdorff, G., \& Essau, C. (1993). Adolescen control beliefs: Cross-cultural variations of primary and secondary orientations. International Journal of Behavioral Development, 16, 243-260.

Shannon, D. K., Oakes, K. E., Scheers, N. J., Richardson, F J., \& Stills, A. B. (2013). Religious beliefs as moderator of exposure to violence in African American adolescents. Psychology of Religion and Spirituality, 5, 172-181. 10.10371 a0030879.

Shweder, R. A., Mahapatra, M., \& Miller, J. G. (1990). Culture and moral development. In J. W. Stigler, R. A. Shweder, \& G. Herdt (Eds.), Cultural psychology: Essays on comparative human development (pp. 130-204). New York: Cambridge University Press. 
Shweder, R. A., Much, N. C., Mahapatra, M., \& Park, L. (1997). The "big three" of morality (autonomy, community, divinity) and the "big three" explanations of suffering. In A. M. Brandt \& P. Rozin (Eds.), Morality and health (pp. 119-169). New York: Routledge.

Smith, C. (2011). Lost in transition. Oxford, UK: Oxford University Press.

Super, C. M., \& Harkness, S. (1986). The developmental niche: A conceptualization at the interface of child and culture. International Journal of Behavioral Development, 9, 545-569. doi: 10.1177/016502548600900409

Trommsdorff, G. (1983). Future orientation and socialization. International Journal of Psychology, 18, 381-406. doi: 10.1080/00207598308247489

Trommsdorff, G. (2009a). Culture and development of selfregulation. Social and Personality Psychology Compass, 3, 687-701. doi: 10.1111/j.1751-9004.2009.00209.x

Trommsdorff, G. (2009b). Intergenerational relations and cultural transmission. In U. Schönpflug (Ed.), Cultural transmission: Psychological, developmental, social, and methodological aspects (pp. 126-160). Cambridge, UK: Cambridge University Press.

Trommsdorff, G. (2012a). Development of "agentic" regulation in cultural context: The role of self and world views. Child Development Perspectives, 6, 19-26. doi: $10.1111 / \mathrm{j} .1750-8606.2011 .00224 . x$

Trommsdorff, G. (2012b). Cultural perspectives on values and religion in adolescent development: A conceptual overview and synthesis. In G. Trommsdorff \& X. Chen (Eds.), Values, religion, and culture in adolescent development (pp. 3-45). New York: Cambridge University Press.

Trommsdorff, G., \& Chen, X. (Eds.). (2012). Values, religion, and culture in adolescent development. New York: Cambridge University Press.

Trommsdorff, G., Friedlmeier, W., \& Mayer, B. (2007). Sympathy, distress, and prosocial behavior of preschool children in four cultures. International Journal of Behavioral Development, 31, 284-293.

Trommsdorff, G., \& Iwawaki, S. (1989). Students' perceptions of socialisation and gender role in Japan and Germany.
International Journal of Behavioral Development, 12 485-493.

Trommsdorff, G., \& Mayer, B. (2012). A cross-cultural study of intergenerational relations: The role of socioeconomic factors, values, and relationship quality in intergenerational support. In H. Bertram \& N. Ehlert (Eds.), Family, ties, and care: Family transformation in a plural modernity (pp. 315-342). Berlin: Barbara Budrich.

Trommsdorff, G., \& Nauck, B. (Eds.). (2005). The value of children in cross-cultural perspective. Case-studies from eight societies. Lengerich, GER: Pabst Science.

Trommsdorff, G., \& Rothbaum, F. (2008). Development of emotion regulation in cultural context. In S. Ismer, S. Jung, S. Kronast, C. v. Scheve, \& M. Vandekerckhove (Eds.), Regulating emotions: Social necessity and biological inheritance (pp. 85-120). New York: Blackwell.

Turiel, E. (1983). The development of social knowledge: Morality and convention. New York: Cambridge University Press.

Verkuyten, M., \& Martinovic, B. (2012). Social identity complexity and immigrants' attitude toward the host nation: The intersection of ethnic and religious group identification. Personality and Social Psychology Bulletin, 38, 1165-1177. doi: $10.1177 / 0146167212446164$

Weber, M. (1958). The protestant ethic and the spirit of capitalism. New York: Scribner.

Weisz, J. R., Rothbaum, F. M., \& Blackburn, T. C. (1984). Standing out and standing in: The psychology of control in America and Japan. American Psychologist, 39, 955-969. doi: 10.1037/0003-066X.39.9.955

Yeh, K. -H., \& Bedford, O. (2004). Filial belief and parent-child conflict. International Journal of Psychology, 39, 132-144. doi: $10.1080 / 00207590344000312$

Youniss, J., McLellan, J. A., \& Yates, M. (1999). Religion, community service, and identity in American youth. Journal of Adolescence, 22, 243-253. doi: 10.1006/ jado.1999.0214

Ysseldyk, R., Matheson, K., \& Anisman, H. (2010). Religiosity as identity: Toward an understanding of religion from a social identity perspective. Personality and Social Psychology Review, 14, 60-71. doi: 10.1177/1088868309349693 